\section{Nomenclature of Tahitian Bridal Veil}

\author{
Paul R. Fantz and \\ Paul Nelson
}

\begin{abstract}
Additional index words. floriculture, nomenclature, taxonomy,

Commelinaceae, Gibasis, Tripogandra, Tradescantia

Summary. Tahitian bridal veil traditionally has been assigned the scientific name of Tradescentia multiflora (or Tradescentia multifoila in the floricultural industry. Hortus Third lacks the name Tahitian bridal veil. Other references also lack this vernacular name or assign this plant either to Tripogandra or Gibasis as G. geniculata or G. pellucida. Thus, modern literature references suggest three potential scientific names. Plants of Tahitian bridal veil were examined morphologically. A description was prepared and compared to literature descriptions of the taxa involved. Results indicated that Tahitian bridal veil was misidentified at least twice by earlier authors and that the correct name for Tahitian bridal veil is $G$. pellucida.
\end{abstract}

I n 1993, 43 million foliage and flowering hanging baskets were grown in the United States and marketed as floricultural crops at the wholesale level for \$203 million (U.S. Dept. of Agriculture, 1994). One of these crops used extensively as a hanging basket plant in the United States, Canada, and Europe is Tahitian bridal veil or bridal veil (Fig. 1). Several factors contribute to its popularity. Tahitian bridal veil is propagated easily from terminal and sectional stem cuttings that are rooted

Professors, Department of Horticultural Science, North Carolina State University, Box 7609, Raleigh, NC 276957609.

Research Project NCO 6104 funded in part by the North Carolina Agricultural Research Service, Raleigh, NC 27695-7643, Use of nursery and trade names in this publications does not imply endorsment by the NCARS of the nurseries or the products mentioned nor criticism of similar ones not mentioned. The cost of publishing this paper was defrayed in part by the payment of page charges. Under postal regulations, this paper therefore must be hereby marked advertisement solely to indicate this fact. directly in the hanging basket. Environmental requirements are moderate; the plant requires medium light intensity and temperatures of 13 to 21C (John Henry Company, 1977). Growth is rapid and the creeping form produces a pendulous mound, which is ideal for a hanging basket. The deep green upper surface and purple undersides of leaves blend nicely with many, small, brilliant white flowers to give this plant exceptional sales appeal.

An inquiry by growers was made to faculty members at North Carolina State Univ. regarding the correct scientific name for Tahitian bridal veil. These growers indicated that the name may be Tradescantia multifolia, but they couldn't find this name in a reference. Problems encountered by us in searching the literature for a correct scientific name led to a morphological examination of Tahitian bridal veil to ascertain the correct genus to which it should be assigned.

\section{Taxonomic literature}

The name Tahitian bridal veil is lacking in Hortus Third (Liberty Hyde Bailey Hortorium, 1976) and other references that include floricultural crops (Bailey, 1917, 1949; Graf, 1978, 1982; Hessayon, 1991; Larson, 1992; Perry, 1974). Rathmell (1980) stated that Tahitian bridal veil was Tradescantia multiflora (no authority given). John Henry Company (1977) cited
Tahitian bridal veil as Tradescantia multiflora Swartz, a name similar to a grower's name of Tradescantia multifolia. These two epithets contain the basic Latin roots -folius and -florus, translated by Stearn (1992) as leaved and flower, respectively. These two Latin root words also appear in other epithets (e.g., grandifolia and grandiflora, parvifolia, and parviflora). These epithet pairs are similar in length, spelling, and appearance. Thus, each member of the pair is confused commonly with the other member by students in plant material courses and members of the landscape, nursery, and floricultural industries.

Hortus Third lacked the name Tradescantia multifolia, but cited the name Tradescantia multiflora as a synonym of Tripogandra multiflora (Swartz) Raf. Everett (1982), and Huxley (1992) listed Tripogandra multiflora with a brief description that could fit bridal veil. However, neither the vernacular name Tahitian bridal veil nor Tradescantia multiflora was cited under either Tripogandra Raf. or Tradescantia L. Graf (1978, 1982) cited Tradescantia multiflora as a synonym of Gibasis geniculata (Jacq.) Rohw. Hortus Third reported G. geniculata as sometimes cultivated as a laboratory plant, but not offered in the trade.

Everett (198 1) reported Tahitian bridal veil as a selected form of $\mathrm{G}$.

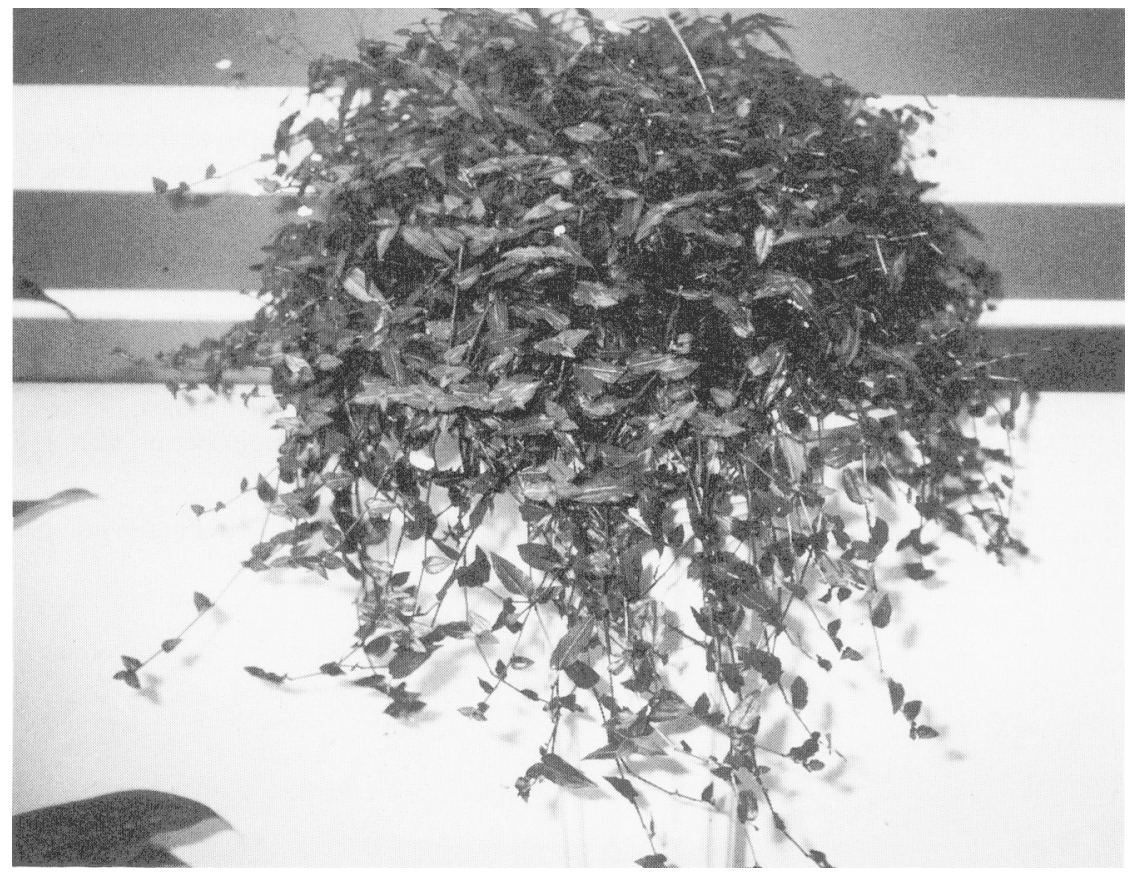

Fig. 1. Habit of Tahitian bridal veil as a hanging basket floricultural crop. 
Table 1. Morphological comparison of three gemra of Commelinaceae.

\begin{tabular}{lccc}
\hline Character & Tripogandra & Tradescantia & Gibasis \\
\hline $\begin{array}{l}\text { Inflorescence } \\
\text { Stipe }\end{array}$ & Lacking & Lacking & Present \\
Cincinni & Fused & Fused & Free \\
Bracts & Conspicuous & Inconspicuous \\
Flowers & Zygomorphic & Actinomorphic & Actinomorphic \\
Symmetry & Long and short & Subequal & Subequal \\
Stamens & Three curved & Straight & Straight \\
Length & Bearded or glabrous & Bearded & Bearded \\
Filament & Narrow & Broad & Triangular \\
Trichomes & Connective & &
\end{tabular}

geniculata and cited Tradescantia geniculata Jacq. and Aneilema geniculatum (Jacq.) Woodson in synonymy, but he did not use the name Tradescantia multiflora. Also cited was a close relationship of G. geniculata with G. oaxacana D.R. Hunt. Huxley (1992) associated the name bridal veil with G. pellucida (Martens \& Gal.) D. Hunt. and noted that, under the entry G. geniculata, it is often confused with G. pellucida in cultivation. Everett (1981) described G. geniculata with hairless leaves, whereas Huxley (1992) described G. geniculata as bearing villous leaves.

Hunt (1986) associated bridal veil with G. pellucida but did not cite Tradescantia multiflora in synonymy, nor is Tradescantia multiflora cited in synonymy with G. geniculata.

Although Tahitian bridal veil is a well-known plant in the floricultural trade, its correct scientific name is not clear. Literature references suggest the following choices: 1) Tripogandra multiflora, 2) G. geniculata, or 3) G. pellucida or G. oxacana. Which name should horticulturists accept?

\section{Taxonomic evidence}

Plants of Tahitian bridal veil (Fig. 1) obtained from commercial sources were grown under greenhouse conditions at North Carolina State Univ., examined, and described morphologically from first-hand observation. The description presented below was the taxonomic evidence we used for comparison with literature descriptions to determine the correct identification of Tahitian bridal veil.

“Tahitian bridal veil." Stems creeping to decumbent, branching and rooting at the nodes; twigs slender, terete, to $1 \mathrm{~mm}$ diam., glabrate with scattered minute trichomes and one conspicuous row of erect trichomes (ca $0.1-0.2 \mathrm{~mm}$ ) from node to node on the opposite side from the leaf blade above. LEAVES asymmetrical, nearly distichate on twig, subsessile on the sheath, $1-5 \mathrm{~cm}$ long, 0.3-1.6 (3) $\mathrm{cm}$ wide, blade ovate to narrowly oblong to ovate-lanceolate to lanceolate, entire, acute to short acuminate, obliquely cordate, glabrate, dark green above, green to reddish-purple below, lateral veins 2-4/side; sheath closed, striate, $24 \mathrm{~mm}$ long, sericeousciliate on upper edge (trichomes 34 $\mathrm{mm}$ ), ascending-spreading sericeous (trichomes $14 \mathrm{~mm}$ ) on the surface. INFLORESCENCES borne from upper axils and seemingly terminal, stipitate. Cincinni free, binate above stipe. Stipe green, 12-24 mm long. Peduncular bracts 2, membranous, narrow concavelanceolate around peduncle, acute, sericeous, $1.8-2.5 \mathrm{~mm}$ long, ca $0.3-0.6 \mathrm{~mm}$ wide. Peduncles green, $12-17 \mathrm{~mm}$ long. Bracts inconspicuous, imbricate, ovate, membranous, acute, to $1 \mathrm{~mm}$ long, ca $0.7-0.8 \mathrm{~mm}$ wide. Pedicels in flower purple to blackish-purple, 7-14 $\mathrm{mm}$ long. Bracteoles 2, ovate, translucent, to 1 $\mathrm{mm}$ long. FLOWERS with only one open per cincinni. Sepals 3, green, elliptic-navicular, weakly keeled, acute, 2$2.2 \mathrm{~mm}$ long, $1 \mathrm{~mm}$ wide. Petals 3 , white, ovate-orbicular, broadly obtuse, $3.64 \mathrm{~mm}$ long, $3.54 \mathrm{~mm}$ wide at base. Stamens 6, subequal, white, bearded basally and near apex; filaments 2.5-2.8 $\mathrm{mm}$ long; anthers versatile, yellow, connective deltoidal; trichomes dense, spreading in a rosette pattern, moniliform, basal set 1.5-2 $\mathrm{mm}$ long, apical set ca $0.5-0.8 \mathrm{~mm}$ below anthers, to $1 \mathrm{~mm}$ long. Pistil white; ovary 3-locular, ca 0.6-0.8 mm long; style slightly exerted beyond stamens, $3 \mathrm{~mm}$ long; stigma capitellate. Fruits not observed.

\section{Taxonomic identification}

The first step in identification was to determine the genus to which Tahitian bridal veil should be assigned. There were three possible genera: Tripogandra, Tradescantia, and Gibasis. Characters used for segregating the genera are compared in Table 1. Tahitian bridal veil is not a

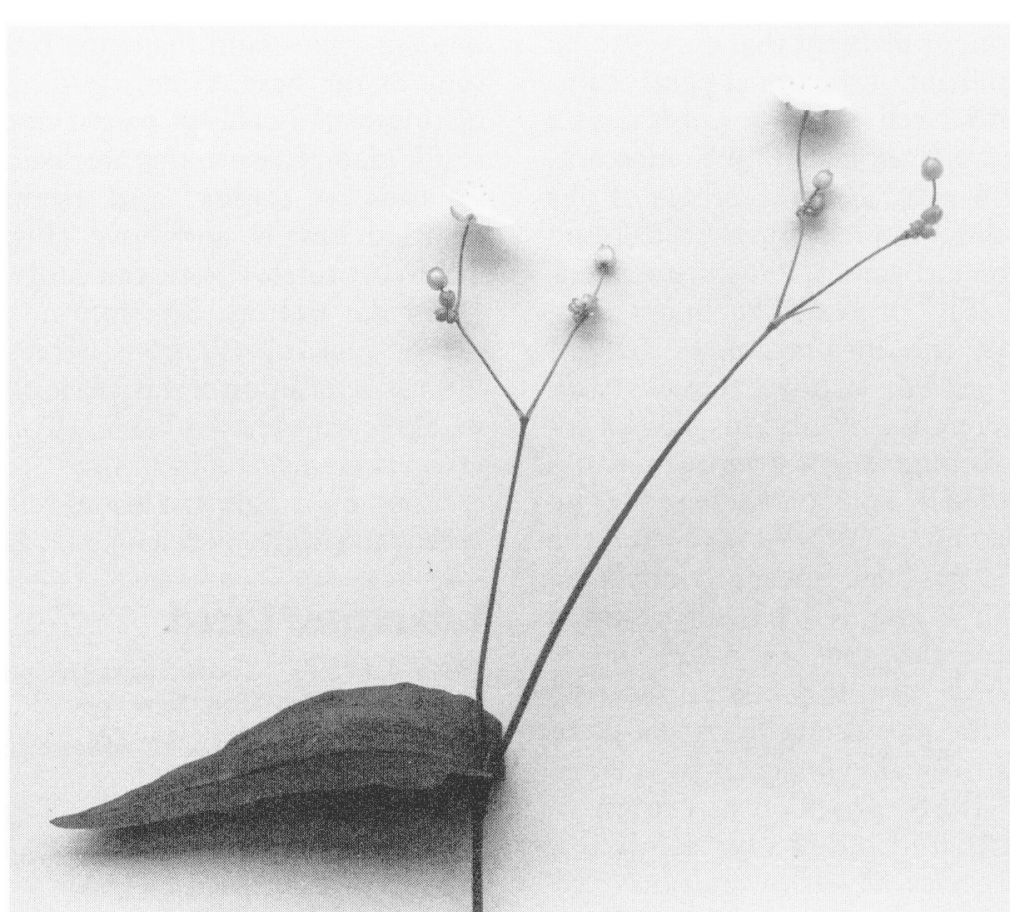

Fig. 2. Axillary inflorescence of Tahitian bridal veil with its paired, stalked, free cincinni. 


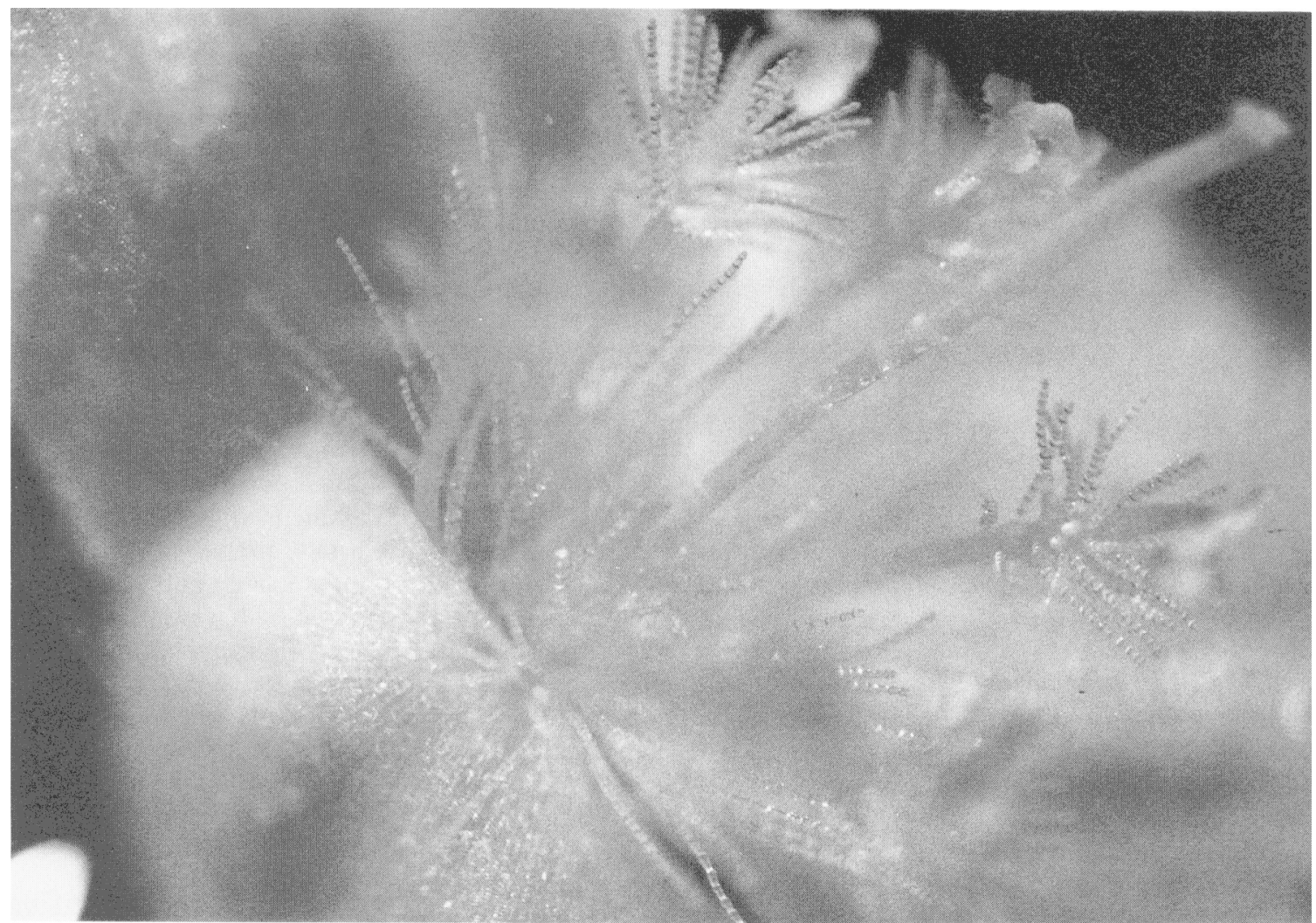

Fig. 3. Stamens of a flower of Tahitian bridal veil bearded basally and apically.

Tripogandra (Greek tri-, three; pogon, beard; andros, male). Members of this genus differ from Tahitian bridal veil by possessing zygomorphic flowers; sessile, fused cincinni; a narrow anther connective; and unequal stamens, with the inner whorl of three stamens bearing a longer filament that curves to be erect in front of the upper petal. Tahitian bridal veil is not a Tradescantia (named in honor of John Tradescant, a British naturalist). Members of this genus differ by possessing sessile, fused cincinni and paired, conspicuous, enlarged leaf- or boat-like bracts subtending the inflorescence. Gibasis (Latin gibbus, swollen; Greek basis, base; reference to gibbous base of sepals) is distinguished by the free cincinni subtended by a pair of bracts and borne on a prominent stipe (Fig. 2) and the broad triangular anther connective. Tahitian bridal veil has all of these characteristics; thus it is a Gibasis.

The second step in identification was to identify the correct species of Tahitian bridal veil within the genus. Hunt (1986) provided a revision of Gibasis that included a key to species. Most species have flowers purple to violet-blue to pink, not white. There are three white-flowering species.
Gibasis oaxacana is distinguished easily by bearing three to eight cincinni in an umbel and petiolate leaves spirally arranged. Gibasis geniculata is distinguished easily by having paired cincinni; sessile, densely villous leaves that are distichate [2-ranked]; glandular-pubescent stipes; and filaments bearded only at the base. Gibasis pellucida is distinguished easily by paired cincinni, sessile glabrate leaves that are distichate, eglandular stipes, and filaments bearded basally and above (Fig. 3). Tahitian bridal veil keys out easily to $G$. pellucida, and our description, based on first-hand observations, agrees with Hunt's description of this species. Thus, we agree with Huxley (1992) from our taxonomic investigation that the correct name for Tahitian bridal veil is $\mathrm{G}$. pellucida (Martens\& Gal.) D. Hunt.

\section{Literature Cited}

Bailey, L.H. 1917. The standard cyclopedia of horticulture. Macmillan, New York.

Bailey, L.H. 1949. Manual of cultivated plants. Macmillan, New York.

Everett, T.H. (cd.). 1981. The New York Botanical Garden illustrated encyclopedia of hortculture. vol. 3. Garland, New York.

Everett, T.H. (cd.). 1982. The New York Botanical Garden illustrated encyclopedia of horti- culture. vol. 10. Garland. New York. p. 3376$3379,3407$.

Graj A.B. 1978. Tropics. Roehrs Co., East Rutherford, N.J.

Graj A.B. 1982. Exotica. Roehrs Co., East Rutherford, N.J.

Hessayon, D. G. 1991. The new house plant expert. Jarrold \& Sons, Norwich, U.K

Hunt, D.R. 1986. A revision of Gibasis Rafin. Amer. Commelinaceae XII. KewBul. 41(1):107129.

Huxley, A. 1992. The new Royal Horticultural Society dictionary of gardening. Morton Word Processing Ltd., Scarborough, U.K. p. 410; 494-495,513.

JohnHenry Company. 1977. John Henry's guide to green plants. John Henry Co., Lansing, Mich. Larson, R.A. (ed.). 1992. Introduction to floriculture. 2nd ed. Academic Press, San Diego.

Liberty Hyde Bailey Hortorium. 1976. Hortus third. Macmillan, New York.

Perry, F. (cd.). 1974. Simon \& Schuster's complete guide to plants and flowers. Simon \& Schuster, New York.

Rathmell, J.K., Jr. 1980. Hanging baskets, p. 525-553. In: RA. Larson (cd.). Introduction to floriculture. Academic Press, New York.

Steam, W.T. 1992. Botanical Latin. 4th ed. Redwood Press Ltd., Devon, U.K.

U.S. Department of Agriculture. 1994. Floriculture crops 1993 summary. U.S. Dept. of Agr., Natl. Agr. Stat. Ser., Agr. Stat. Board. Wash., D.C. Sp. Cr. 6-1(94). 